\title{
EFFECTS OF SHADE TREES SPATIAL DISTRIBUTION AND SPECIES ON PHOTOSYNTHETIC RATE OF COFFEE TREES
}

\author{
Francisco José da Silva Neto ${ }^{1}$, Leila Bonfanti², Rodrigo Gazaffi ${ }^{3}$, Anastácia Fontanetti ${ }^{4}$
}

(Received: April 26, 2019; accepted: June 27, 2019)

\begin{abstract}
The use of shade trees in coffee fields have been motivated by climatic changes. However, microclimatic conditions in shaded coffee fields differ due to shade tree spatial distribution and species, altering physiological responses of coffee trees. This study aimed to evaluate the effects of shade tree spatial distribution and species on coffee trees photosynthetic rate in two growth seasons, of high (HSD) and low (LSD) sink demand. The experimental design consisted of randomized blocks with three replicates in split-split-plots. Plots were the shade tree species: Anadenanthera falcata, Cassia grandis and Peltophorum dubium. Split plot was formed by five distances between coffee trees and shade tree trunks: coffee trees on planting row of shade trees, distancing one (D1L) and five (D5L) meters from shade trees trunk; coffee trees on inter-rows of shade trees, parallel to D1L and D5L (D1E and D5E); coffee trees distancing 77 meters from shade tree trunks, in a full-sun field (PS). The split-split-plots correspond to coffee tree canopy exposure to the sun: branches facing North or South. Shade trees canopy density and occupation was evaluated with a convex densiometer. Photosynthetic rate $\left(P_{n}\right)$ and photosynthetic active radiation (PAR) were measured with an Infrared Gas Analyzer (IRGA) on two time-frames, between 7.00 and 9.00 solar hours and between 11.00 and 13.00. Shade tree canopy density and occupation was not homogenous during the change of seasons and shift due to spatial distribution, which also changes $P A R$ levels. Shade trees reduce $P A R$ to more suitable values for coffee tree exploitation, especially on D1L and D5L. During HSD, shading did not affect $P_{n}$, which was greater in branches facing North. Yet, in LSD, between 11.00 and 13.00, coffee trees shaded with A. falcata showed greater $P_{n}$ than at PS. Coffee trees shaded with $C$. grandis at D5L and D1E had greater values of $P_{n}$ than PS.
\end{abstract}

Index terms: Agroforestry systems, canopy density, canopy occupation rate, physiology, photosynthetic active radiation.

\section{EFEITO DA DISTRIBUIÇÃO ESPACIAL E DE ESPÉCIES ARBÓREAS NA TAXA DE FOTOSSÍNTESE DE CAFEEIROS SOMBREADOS}

RESUMO: A implantação de árvores em lavouras cafeeiras tem sido estimulada pelas mudanças climáticas. Entretanto, as condições microclimáticas nas lavouras cafeeiras sombreadas variam em função da espécie e da distribuição espacial das árvores, alterando as respostas fisiológicas do cafeeiro. Objetivou-se avaliar os efeitos da distribuição espacial e das espécies arbóreas na taxa fotossintética de cafeeiros em época de crescimento com alta (HSD) e baixa (LSD) demanda energética. O delineamento experimental foi o de blocos casualizados com três repetições, em esquema de parcelas sub-subdivididas. Sendo as parcelas as espécies arbóreas: Anadenanthera falcata, Cassia grandis e Peltophorum dubium; a subparcela, cinco distâncias em relação aos troncos das árvores avaliadas: cafeeiros localizados na linha de plantio das árvores, a um (D1L) e cinco (D5L) metros de distância do tronco das árvores, cafeeiros localizados na entrelinha de plantio das árvores, paralelos a D1L e D5L (D1E e D5E) e PS, cafeeiros localizas a 77 metros do tronco das árvores, incidindo em um talhão a pleno sol; e as sub-subparcelas corresponderam às faces de exposição solar dos cafeeiros, Norte e Sul. A densidade do dossel foi avaliada com densiômetro convexo. A taxa fotossintética foi avaliada juntamente com a radiação fotossinteticamente ativa $(P A R)$ com o analisador de gases no infravermelho (IRGA - Infra Red Gases Analyser) em dois horários, das 07:00 às 9:00h e das 11:00 às 13:00h. A densidade e ocupação do dossel pelas espécies arbóreas não é homogênea ao longo do ano e sofre alterações em função da distribuição espacial no cafezal, o que resulta em variações na $P A R$. As árvores reduzem a $P A R$ para níveis mais propícios ao aproveitamento do cafeeiro, principalmente na linha de plantio das mesmas. Em HSD o sombreamento não reduziu a taxa fotossintética e essa foi maior na face de exposição solar Norte. Já em LSD, no período das 11:00 as 13:00h, os cafeeiros sombreados por A. falcata, independente da distribuição espacial, apresentaram taxas fotossintéticas superiores aos cafeeiros em PS. Cafeeiros sombreados por C. grandis em D5L e D1E apresentaram taxas fotossintéticas maiores que os cafeeiros em PS.

Termos para indexação: Densidade do dossel, fisiologia, radiação fotossinteticamente ativa, sistemas agroflorestais, taxa de contribuição para o dossel.

\section{INTRODUCTION}

Coffee trees (Coffea arabica L.) show little photosynthetic capacity when grown under full sun (RONQUIM et al., 2006). Under this condition, photosynthetic active radiation $(P A R)$ reaches levels of $2,000 \mu \mathrm{mol} \mathrm{m} \mathrm{m}^{-2}$ (TAIZ et al., 2017), while the light-saturation point of coffee tree leaves happens between 300 and $700 \mu \mathrm{mol} \mathrm{m}^{-2} \mathrm{~s}^{-1}$ (DaMATTA, 2004). Thus, high light incidence can damage photosystems (TAIZ et al., 2017), mostly if associated with high temperatures (CAMARGO, 2010). Temperature stress, added to water shortage, leads to branch dieback, a physiological disturb that may inflict in severe yield loss (SILES; HARMAND; VAAST,

1,2,3,4Universidade Federal de São Carlos/UFSCar - Centro de Ciências Agrárias - Rodovia Anhanguera, Km 174 - SP-330 Araras - SP - 13.600-970 - franciscojose331@gmail.com, leila_bonfanti@hotmail.com,rgazaffi@gmail.com, anastacia@ufscar.br 
2010). Also, under full sun conditions, biennial bearing due to overproduction may happen (JARAMILLO-BOTERO et al., 2010; SILES; HARMAND; VAAST, 2010).

Therefore, shading coffee fields has gained interest of coffee farmers and researchers. Shade trees decrease air, soil and leaf temperature (PEZZOPANE et al., 2011; RICCI et al., 2013), reduce thermal amplitude (FRANCK; VAAST, 2009) and wind velocity, creating more suitable microclimatic conditions to gas exchange among coffee trees (PEZZOPANE et al., 2011). Shade also alters coffee tree physiology in a way that $P A R$ becomes more limiting to photosynthesis than stomatal conductance (FRANCK; VAAST, 2009).

The use of different species and the trees position for intercropping with coffee can result in different levels of shade and interspecific competition. When shade trees are far apart, microclimatic conditions are not consistent (PEZZOPANE et al., 2011). Thus, shade trees spatial distribution creates different levels of competitions, the benefits of shade and microclimatic variations, as coffee trees distance from the trunk.

Furthermore, the species of shade tree affects PAR interception (COELHO et al., 2010), evaporative rates (PADOVAN et al., 2018; PADOVAN et al., 2015), air (RICCI et al., 2013; VALENTINI et al., 2010) and soil temperature, as well as thermal amplitude (RICCI et al., 2013).

This study aimed to analyze the effects of different shade tree species and their spatial distribution on shade coffee fields at the photosynthetic rates of coffee trees in growth seasons of high and low sink demand.

\section{MATERIAL AND METHODS}

\section{Study site characterization}

This experiment was carried out at Fazenda Retiro Santo Antônio, located in Santo Antonio do Jardim (22 08'42”'S, 46 41'50"W) in São Paulo state, Brazil. Data was recorded between March $9^{\text {th }}$ and April $6^{\text {th }}$, for coffee trees in high sink demand season and between September $5^{\text {th }}$ and $23^{\text {th }}$, for low sink demand, in 2018. Average mean temperatures during the year of the experiment were $25.8^{\circ} \mathrm{C}$ $\left(31.0^{\circ} \mathrm{C}\right.$ of mean maximum and $20.9^{\circ} \mathrm{C}$ of mean minimum) and $1,079 \mathrm{~mm}$ of accumulated rainfall.

Two adjacent sites were used. One was an agroforestry system consisting of 'IAC
Obatã' coffee trees (spaced $1.0 \times 3.5 \mathrm{~m})$, East to West rows-oriented, shaded by Anadenanthera falcata (Benth.) Speg.; Cassia grandis L. f. and Peltophorum dubium (Speg.) Taub. (spaced 15.0 x 14.0m), implanted in 2010. Soil was classified as typically distrophic $\mathrm{Tb}$ haplic cambisol by Oliveira (2018). The second site, a full sun field, had coffee trees of the same variety and year of implantation, but with red yellow cambisol soil (EMBRAPA, 2006) (Figure 1). Both sites were located between 878 and 894 meters of altitude, had declivity between 3 and $5^{\circ}$ and faced Northwest (ALMEIDA, 2016). A description of the main characteristics of the evaluated shade trees is available in Table 1.

The experimental design consisted of randomized blocks with three replicates in splitsplit plots. The plots consisted of the shade tree species: Anadenanthera falcata, Cassia grandis and Peltophorum dubium; split plot was formed by five distances between coffee trees and shade tree trunks: coffee trees on planting rows of shade trees, distancing one (D1L) and five meters (D5L) from shade trees trunk; coffee trees on inter-rows of shade trees, parallel to D1L and D5L (D1E and D5E); coffee trees distancing 77 meters from shade tree trunks, in a full-sun field (PS); and split-split plots correspond to coffee tree canopy exposure to the sun: branches facing North or South. Experimental units consisted of six coffee trees, three consecutive plants at each side of shade trees trunk. However, for treatments D1E and PS, six consecutive coffee trees were used (Figure 1 B).

\section{Canopy density and canopyoccupation rate}

Shade tree canopy density was evaluated in September 2018 and March 2019 with Lemmon's convex spherical densiometer. Measurements took place twice in each experimental unit, once at each trunk side (as shown in figure $1 \mathrm{~B}$ ), distancing one meter from the coffee tree crown, according to Lemmon (1954).

Canopy Occupation Rate of the shade tree under evaluation was calculated as follows:

$$
\operatorname{COR}=\frac{\mathrm{A}}{\left(\mathrm{A}+\mathrm{A}^{\prime}\right)}
$$

Where COR is the canopy occupation rate of the shade tree under evaluation. A is the percentage of canopy occupation by the shade tree under evaluation and $A^{\prime}$ the percentage of canopy occupation by the sum of all other trees that appeared in the analysis. 
TABLE 1 - Diameter at breast high (DBH), height $(\mathrm{H})$ and Crown shape of shade trees. Santo Antônio do Jardim, SP, 2018.

\begin{tabular}{cccc}
\hline & DBH $^{\mathbf{1}}$ & $\mathbf{H}^{\mathbf{2}}$ & Crown shape $^{\mathbf{3}}$ \\
\hline Species & $---\mathbf{c m}$--- & $----\mathbf{~ m}$---- & \\
\hline Anadenanthera falcata & 32.2 & 16.0 & Horizontal elliptical \\
Cassia grandis & 34.5 & 11.7 & Globose \\
Peltophorum dubium & 34.7 & 15.9 & Caliciform \\
\hline
\end{tabular}

Values correspond to the mean between the tree specimens evaluated for each species.

$1 \mathrm{DBH}$ values were obtained with the formula $\mathrm{DBH}=$ circumference at breast height $/ \pi$; circumference was measured with a measuring tape.

2 Tree heights were measured with the mobile app iHypsometer Lite 1.0.3 (Lima, 2016).

3 Canopy shape was determined according to the classification proposed by Andrade, Salman and Oliveira (2012).
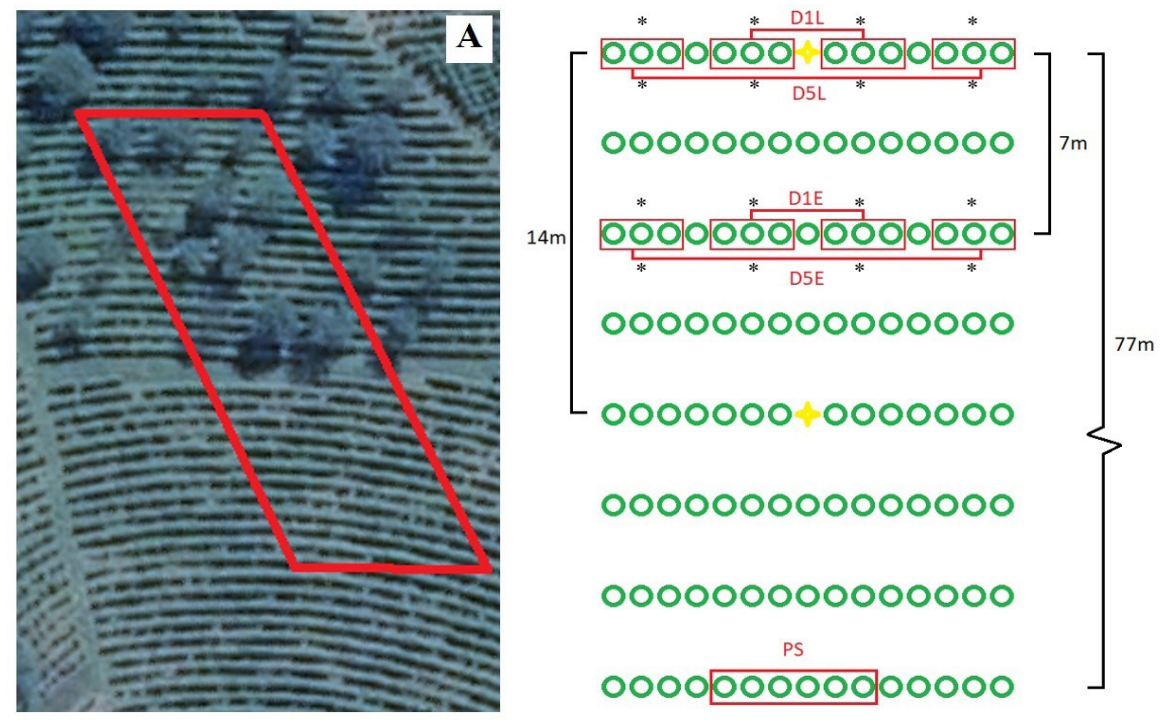

B

Coffee trees

Shade trees

* Densiometer sampling points

FIGURE 1 - Satellite image of the study site and experimental design, with delimitation of treatments. Santo Antônio do Jardim, SP, 2019.A. In red, delimitation of study site; B. Coffee trees on planting row of shade trees, distancing one and five meters from the trunk (D1L and D5L); coffee trees on inter-rows of shade trees, parallel to D1L and D5L (D1E and D5E); coffee trees distancing 77 meters from shade tree trunks, in a full sun field (PS).

\section{Photosynthetic rate and photosynthetic active radiation}

Photosynthetic rate $\left(P_{n}\right)$ and photosynthetic active radiation $(P A R)$ were obtained with an infrared gas analyzer (IRGA, model LCA Pro). Measurements took place at two time-frames: 7.00-9.00 solar hours and 11.00-13.00, between March 09th and April 06th, 2018, for coffee trees growth high sink demand (HSD), and from March 05th to September 23rd, for coffee tree growth low sink demand (LSD).

Data were collected on cloudless days with natural light and air humidity on the evaluation chamber. Carbonic gas concentration was set for
$400 \mathrm{ppm}$ and air flux in $200 \mu \mathrm{mol} \mathrm{s}{ }^{-1}$. Two leaves per plant in the canopy middle third, four plants per experimental unit were measured, respecting the original position and inclination, as recommended by Chaves et al. (2012). To control eventual environmental variations during data collection, one reference plot, for all treatments, consisting of two coffee trees far from shade trees was added. During all measurements, after 50 minutes of data recording, the reference plot was analyzed.

\section{Statistical analysis}

Data were submitted to variance analysis and means were compared by Tukey's test at 5\% 
significance, with R Studio software. To eliminate environmental variations resulting from the time between collections of $P A R$ and $P_{n}$ values, data from the reference plot was added to the ANOVA as a covariable.

\section{RESULTS AND DISCUSSION}

\section{Shade tree canopy density and canopy occupation rate}

During HSD, shade trees form a denser canopy over branches facing South, 29.8\%, than over northern ones $(27.1 \%)$. Due to the relation between planting orientation, from East to West, and declivity, branches facing South have less light available and tend to grow more, as a physical consequence of light search.

Shade tree spatial distribution affected canopy density during LSD. At D1L, canopy density was greater than at locations on the interrow of shade trees. Still, at D5L, canopy density did not differ from the other locations (Table 2). Moreira (2015) also reported that points distancing $1.4 \mathrm{~m}$ to shade tree Acrocomia aculeata show denser canopy than points distancing $4.2 \mathrm{~m}$. However, the author found canopy density greater than $50 \%$.

The mean canopy density found in this study was $28.16 \%$ during HSD and $19.28 \%$ during LSD. Such values are much closer to ideal shade levels reported by Baliza et al. (2012).

Canopy occupation rate during HSD was greater in shade tree planting rows than inter-rows (Table 3). However, during LSD, the factors shade tree species and spatial distribution interact (Figure 2). The locations D1L and D5L under A. falcata's shade showed greater occupation rates than at D1E and D5E, where the sum of neighbor shading trees was more important for canopy occupation. Among the locations under C. grandis's shade, D1L had a larger contribution of the tree under evaluation to COR. Still, at D5L its contribution was more significant to COR than the sum of other trees. However, locations on C. grandis inter-rows, the canopy had more contribution of the summed surround trees (Figure 2). It is important to notice that this species showed the smallest height (Table 1) and the most compact crown, according to the classification of Andrade, Salman and Oliveira (2012), corroborating the occupation rate findings. These findings suggest a smaller spacing between trees for this species.

\section{Photosynthetic Active Radiation (PAR)}

During HSD, between 07.00 and 09.00, PAR was lowest at D1L and D5L (Figure 3). However, at PS PAR was only greater than D5E. (Figure 3). Pezzopane et al. (2011), also found a reduction in global solar radiation due to shade tree spatial distribution. According to the authors, global radiation transmissivity was reduced to between 20 and $29 \%$ on Grevillea robusta planting rows, directly under tree crowns, when compared to any other point in the agroforestry system, which were at least $83 \%$.

At the same time frame, but on LSD, shade tree species did not affect $P A R$ levels. However, under $A$. falcata and $P$. dubium, coffee tree branches facing North received more PAR than branches facing South. This was not observed under $C$. grandis, where different sides received the same PAR (Figure 4). Chabonnier et al. (2013) reported that, besides canopy density, factors such as leaf and branch allocation patterns and inclination, azimuthal distribution and crown volume also affect canopy radiation transmissivity.

Miah et al. (2018) found increases in PAR in agroforestry systems due to more diffused light. Therefore, $C$. grandis, which has a globular and compact crown, allowing passage only to diffused light, the same kind of radiation found for Southfacing coffee branches, as shown in Figure 4.

During HSD, between 11.00 and 13.00 o'clock, when shade concentrated directly under the shade tree crown, coffee branches facing North received the least $P A R$ at $\mathrm{D} 1 \mathrm{~L}$ and the greatest amount at PS (Figure 5). For branches facing South, where self-shade also occurs, coffee trees at D1L, $500 \mu \mathrm{mol} \mathrm{m}^{-2} \mathrm{~s}^{-1}$, received less PAR than D1E, $1214 \mu \mathrm{mol} \mathrm{m}^{-2} \mathrm{~s}^{-1}$, D5E, $1435 \mu \mathrm{mol} \mathrm{m}^{-2} \mathrm{~s}^{-1}$ and PS, $1553 \mu \mathrm{mol} \mathrm{m}^{-2} \mathrm{~s}^{-1}$. PAR was similar to D5L, $767 \mu \mathrm{mol} \mathrm{m} \mathrm{m}^{-2} \mathrm{~s}^{-1}$, for D1L and D1E. (figure 5). Between the solar exposure sides, branches facing North only received greater PAR at PS (Figure 5).

At the same time frame, but during LSD, shade tree species did not alter PAR (Table 4). Coffee trees at D1L received less $P A R, 858 \mu \mathrm{mol}$ $\mathrm{m}^{-2} \mathrm{~s}^{-1}$, than the ones at D5L and PS, with 1270 and $1378 \mu \mathrm{mol} \mathrm{m} \mathrm{m}^{-2} \mathrm{~s}^{-1}$, respectively. D1E and D5L (1195 and $1071 \mu \mathrm{mol} \mathrm{m}^{-2} \mathrm{~s}^{-1}$ ) equaled the PAR in all treatments. Branches facing North $(1338 \mu \mathrm{mol}$ $\mathrm{m}^{-2} \mathrm{~s}^{-1}$ ) received more PAR than those facing South $\left(970 \mu \mathrm{mol} \mathrm{m}^{-2} \mathrm{~s}^{-1}\right)$ (Table 4).

The values of $P A R$ obtained under shade trees were very close to the coffee tree light saturation point, observed by Ronquim et al. (2006) for the variety IAC Obatã as $831 \mu \mathrm{mol} \mathrm{m}^{-2} \mathrm{~s}^{-1}$. 
TABLE 2 - Shade tree canopy density as a function of tree species, spatial distribution and solar exposure side of coffee trees during growth seasons of high (HSD) and low sink demand (LSD). Santo Antônio do Jardim, SP, 2019.

\begin{tabular}{|c|c|c|}
\hline & HSD & LSD \\
\hline & & ---- \\
\hline \multicolumn{3}{|l|}{ Plot (P) } \\
\hline A. falcata & $31.19 \mathrm{a}$ & $27.63 \mathrm{a}$ \\
\hline C. grandis & 28.49 a & $19.40 \mathrm{a}$ \\
\hline P. dubium & $25.69 \mathrm{a}$ & $10.82 \mathrm{a}$ \\
\hline \multicolumn{3}{|l|}{ Split plot (S) } \\
\hline D1L & $32.13 \mathrm{a}$ & $27.01 \mathrm{a}$ \\
\hline D5L & $29.06 \mathrm{a}$ & $19.86 \mathrm{at}$ \\
\hline D1E & 27.71 a & $15.70 \mathrm{~b}$ \\
\hline D5E & $24.92 \mathrm{a}$ & $14.49 \mathrm{~b}$ \\
\hline \multicolumn{3}{|l|}{ Split-split plot (SS) } \\
\hline Branches facing North & $27.09 \mathrm{~b}$ & $19.91 \mathrm{a}$ \\
\hline Branches Facing South & $29.83 \mathrm{a}$ & $18.66 \mathrm{a}$ \\
\hline \multicolumn{3}{|l|}{ Variation Coefficient (VC) } \\
\hline $\mathrm{VC}(\%)-\mathrm{P}$ & 54.0 & 86.5 \\
\hline $\mathrm{VC}(\%)-\mathrm{S}$ & 27.6 & 49.5 \\
\hline $\mathrm{VC}(\%)-\mathrm{SS}$ & 17.5 & 22.4 \\
\hline
\end{tabular}

Means followed by the same letter do not differ according to Tukey's test at 5\% significance.

Coffee trees on planting row of shade trees, distancing one and five meters from the trunk (D1L and D5L), coffee trees on inter-rows of shade trees, parallel to D1L and D5L (D1E and D5E).

TABLE 3 - Canopy occupation rate (COR) as a function of tree species, spatial distribution and solar exposure side of coffee trees during growth season of high sink demand. Santo Antônio do Jardim, SP, 2019.

\begin{tabular}{|c|c|}
\hline & COR \\
\hline & ---- \% ----- \\
\hline \multicolumn{2}{|l|}{ Plot (P) } \\
\hline A. falcata & $58.19 \mathrm{a}$ \\
\hline C. grandis & $49.62 \mathrm{a}$ \\
\hline P. dubium & $68.01 \mathrm{a}$ \\
\hline \multicolumn{2}{|l|}{ Split plot (S) } \\
\hline D1L & 78.66 a \\
\hline D5L & $72.18 \mathrm{a}$ \\
\hline D1E & $46.69 \mathrm{~b}$ \\
\hline D5E & $36.90 \mathrm{~b}$ \\
\hline \multicolumn{2}{|l|}{ Split-split plot (SS) } \\
\hline Branches facing North & $61.63 \mathrm{a}$ \\
\hline Branches Facing South & $55.59 \mathrm{~b}$ \\
\hline \multicolumn{2}{|l|}{ Variation Coefficient (VC) } \\
\hline $\mathrm{VC}(\%)-\mathrm{P}$ & 58.5 \\
\hline $\mathrm{VC}(\%)-\mathrm{S}$ & 19.8 \\
\hline $\mathrm{VC}(\%)-\mathrm{SS}$ & 15.7 \\
\hline
\end{tabular}

Means followed by the same letter do not differ according to Tukey's test at 5\% significance.

Coffee trees on planting row of shade trees, distancing one and five meters from the trunk (D1L and D5L), coffee trees on inter-rows of shade trees, parallel to D1L and D5L (D1E and D5E). 


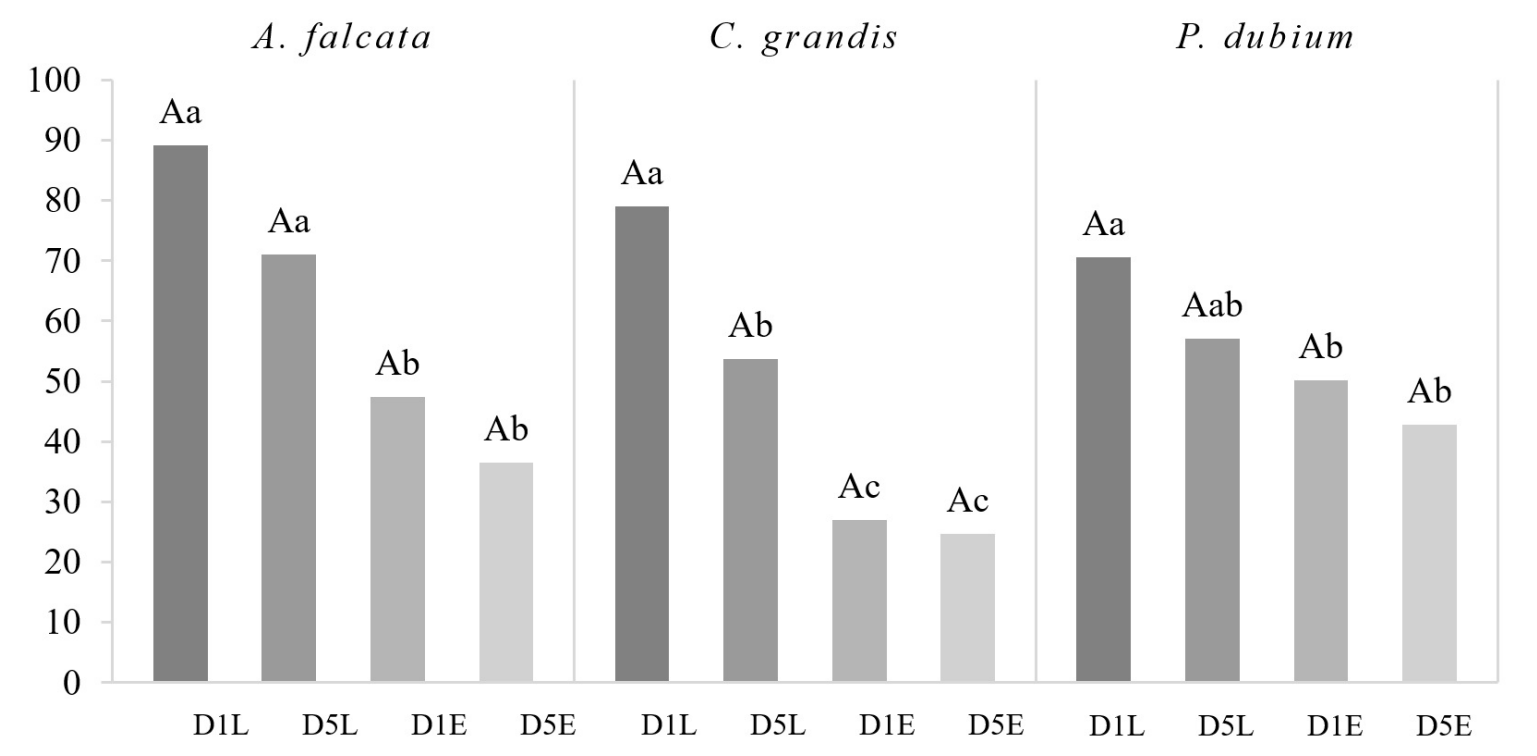

FIGURE 2 - Shade tree canopy occupation rates (COR) as a function of species and spatial distribution during coffee tree growth season of low sink demand. Santo Antônio do Jardim, SP, 2019.Means followed by the same letters, lower case for spatial distribution and capital for species, do not differ according to Tukey's test at 5\% significance.Coffee trees on planting rows of shade trees, distancing one and five meters from the trunk (D1L and D5L), coffee trees on inter-rows of shade trees, parallel to D1L and D5L (D1E and D5E).

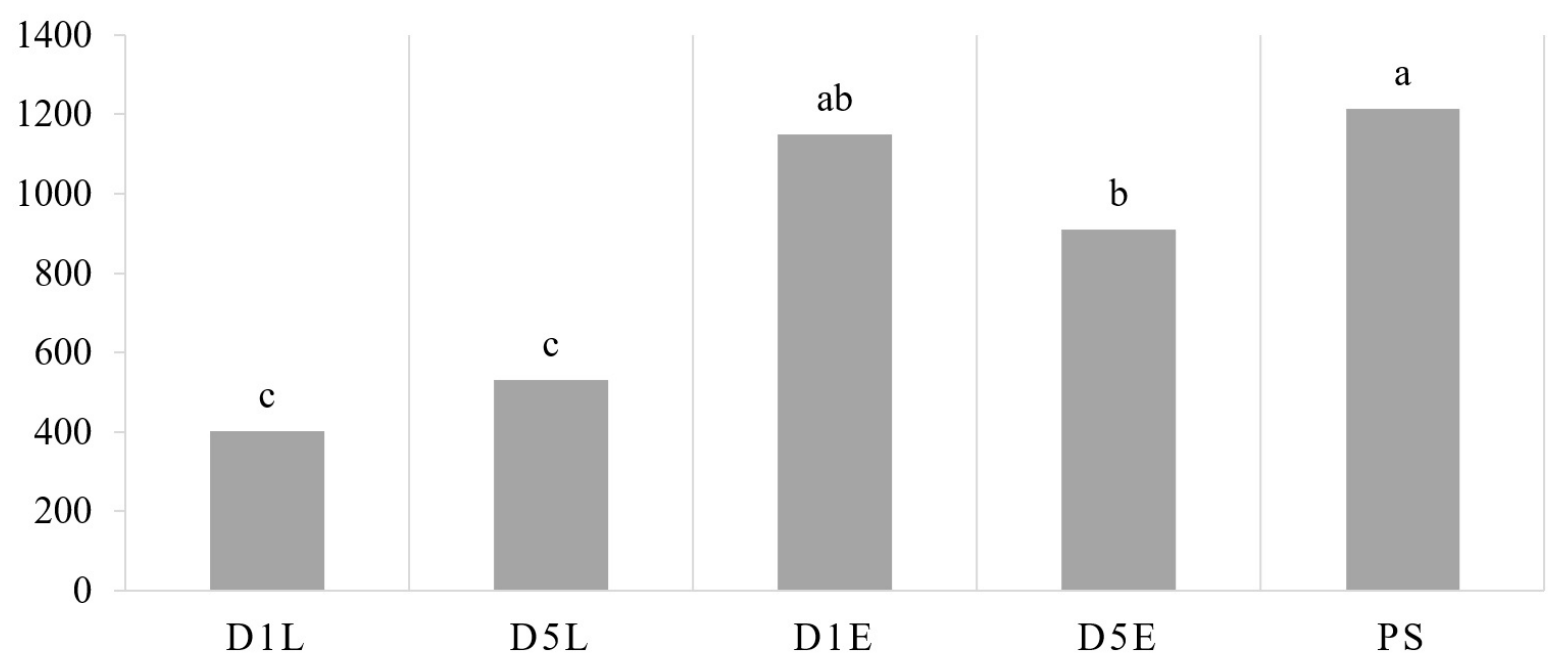

FIGURE 3 - Photosynthetic Active Radiation $(P A R)$ in 'IAC Obatã' coffee trees as a function of shade tree species and spatial distribution between 07.00 and 09.00 (solar time), during coffee tree growth season of high sink demand. Santo Antônio do Jardim, SP, 2019.Means followed by the same letters, lower case for spatial distribution and capital for species, do not differ according to Tukey's test at 5\% significance.Coffee trees on planting rows of shade trees, distancing one and five meters from the trunk (D1L and D5L), coffee trees on inter-rows of shade trees, parallel to D1L and D5L (D1E and D5E); coffee trees distancing 77 meters from shade tree trunks, in a fullsun field (PS). 


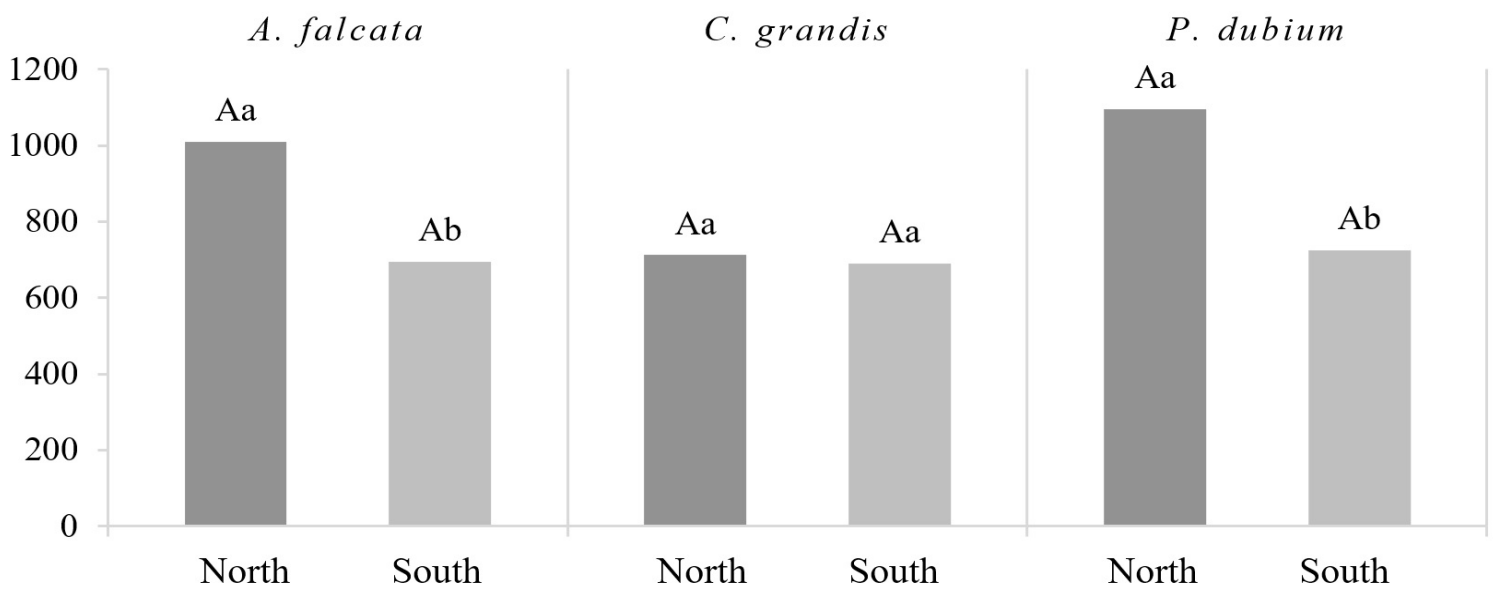

FIGURE 4 - Photosynthetic Active Radiation $(P A R)$ in 'IAC Obatã' coffee trees as a function of shade tree species and coffee tree solar exposure side between 07.00 and 09.00 (solar time) during coffee tree growth season of low sink demand. Santo Antônio do Jardim, SP, 2019. Means followed by the same letters, lower case for coffee tree solar exposure side and capital to shade tree species, did not differ according to Tukey's test at $5 \%$ significance.

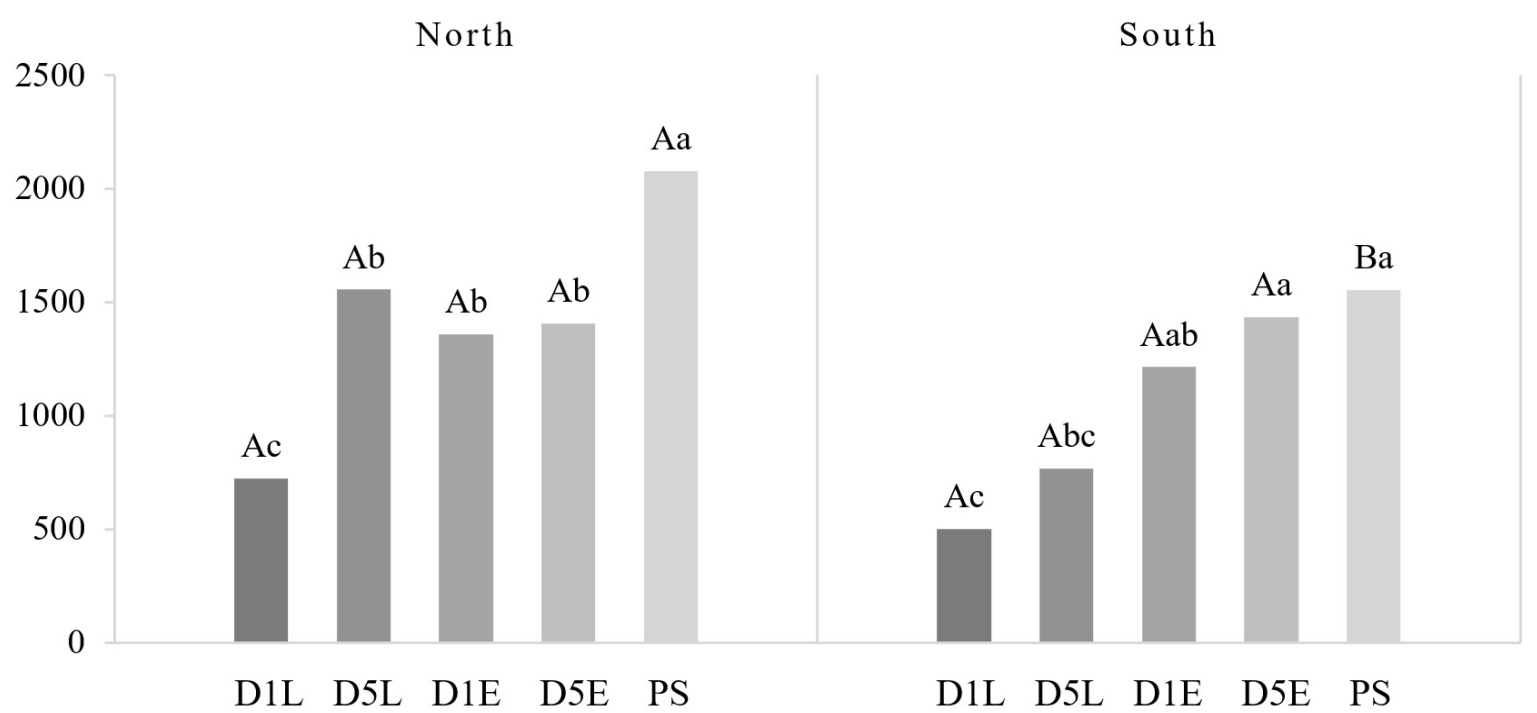

FIGURE 5 - Photosynthetic Active Radiation $(P A R)$ in 'IAC Obatã' coffee trees as a function of shade tree spatial distribution and coffee tree solar exposure side between 11.00 and 13.00 (solar time) during coffee tree growth season of high sink demand. Santo Antônio do Jardim, SP, 2019.Means followed by the same letters, lower case for spatial distribution and capital for coffee tree solar exposure side, do not differ according to Tukey's test at 5\% significance.Coffee trees on planting rows of shade trees, distancing one and five meters from the trunk (D1L and D5L), coffee trees on inter-rows of shade trees, parallel to D1L and D5L (D1E and D5E); coffee trees distancing 77 meters from shade tree trunks, in a full-sun field (PS). 
TABLE 4 - Photosynthetic Active Radiation $(P A R)$ in 'IAC Obatã' coffee trees as a function of shade tree species, spatial distribution and coffee tree solar exposure side between 11.00 and 13.00 (solar time) during coffee tree growth season of low sink demand. Santo Antônio do Jardim, SP, 2019.

\begin{tabular}{|c|c|}
\hline & PAR \\
\hline & ---- $\mu \mathrm{mol} \mathbf{m}^{-2} \mathbf{s}^{-1}$---- \\
\hline \multicolumn{2}{|l|}{ Plot (P) } \\
\hline A. falcata & 1181.13 a \\
\hline C. grandis & $1112.24 \mathrm{a}$ \\
\hline P. dubium & $1168.82 \mathrm{a}$ \\
\hline \multicolumn{2}{|l|}{ Split plot (S) } \\
\hline D1L & $857.58 \quad b$ \\
\hline D5L & 1269.79 a \\
\hline $\mathrm{D} 1 \mathrm{E}$ & $1195.39 \mathrm{ab}$ \\
\hline D5E & $1070.65 \mathrm{ab}$ \\
\hline PS & $1377.62 \quad \mathrm{a}$ \\
\hline \multicolumn{2}{|l|}{ Split-split plot (SS) } \\
\hline Branches facing North & 1337.64 a \\
\hline Branches Facing South & $970.49 \quad b$ \\
\hline \multicolumn{2}{|l|}{ Variation Coefficient (VC) } \\
\hline $\mathrm{VC}(\%)-\mathrm{P}$ & 58.5 \\
\hline $\mathrm{VC}(\%)-\mathrm{S}$ & 19.8 \\
\hline $\mathrm{VC}(\%)-\mathrm{SS}$ & 15.7 \\
\hline
\end{tabular}

Means followed by the same letter do not differ according to Tukey's test at 5\% significance.

Coffee trees on planting rows of shade trees, distancing one and five meters from the trunk (D1L and D5L), coffee trees on inter-rows of shade trees, parallel to D1L and D5L (D1E and D5E); coffee trees distancing 77 meters from shade tree trunks, in a full-sun field (PS).

Therefore, it is possible to assume that shade trees did not negatively affect $P A R$. Although, the distance between shade trees allowed $P A R$ to be greater than coffee trees light saturation point.

The behavior of PAR reduction, greater due to closeness to shade tree trunks, followed an expected logic pattern. However, Soares et al. (2002) showed that this logical distribution is affected by the sun angle, which changes during the year and as a function of site declivity. Therefore, this rule may not apply to locations further from the Equator or with greater declivity than the ones of the study site analyzed.

\section{Photosynthetic rate $\left(\boldsymbol{P}_{n}\right)$}

$P A R$ was much greater at PS than at D1L between 7.00 and 9.00 on high sink demand of coffee trees. However, $P_{n}$ was similar between the treatments, varying from 3.21 to $4.96 \mu \mathrm{mol} \mathrm{m}^{-2} \mathrm{~s}^{-1}$ (Table 5). This indicates an increase in light use efficiency. According to Charbonnier et al. (2017), a reduction up to $60 \%$ in $P A R$ is compensated by an increase of $50 \%$ in light use efficiency, allowing similar $P$ values, even with reductions in PAR. The relatively low values of $P_{n}$ in March, averaging $3.7 \mu \mathrm{mol} \mathrm{m}^{-2} \mathrm{~s}^{-1}$, were also reported by Araujo et al. (2008) and Chaves et al. (2012), for coffee trees under full sun.

Coffee branches facing North showed superior $P_{n}$ than those facing South (Table 5). Araujo et al. (2008) did not find differences between $P_{n}$ in opposite coffee branches. However, their planting orientation, North-South, did not stimulate selfshading. Still, the authors found differences in $P_{n}$ of leaves on higher and lower positions in coffee trees. The $P A R$ reductions due to position were similar to the ones observed in this study. This indicates that the shade levels of this study were enough to make PAR more limiting to $P_{n}$ than stomatal conductance, changing coffee tree physiology, as reported by Frank and Vaast (2009). 
TABLE 5 - Photosynthetic rate $\left(P_{n}\right)$ of 'IAC Obatã' coffee trees as a function of shade tree species, spatial distribution and coffee tree solar exposure side between 07.00 and 09.00 (solar time), during coffee tree growth season of high sink demand. Santo Antônio do Jardim, SP, 2019.

\begin{tabular}{|c|c|c|}
\hline & \multicolumn{2}{|c|}{$P_{n}$} \\
\hline & \multicolumn{2}{|c|}{------ $\mu \mathrm{mol} \mathbf{m}^{-2} \mathbf{s}^{-1}$------ } \\
\hline & $07.00-9.00$ & $11.00-13.00$ \\
\hline \multicolumn{3}{|l|}{ Plot (P) } \\
\hline A. falcata & $4.02 \mathrm{a}$ & $2.44 \mathrm{a}$ \\
\hline C. grandis & $3.40 \mathrm{a}$ & $2.24 \mathrm{a}$ \\
\hline P. dubium & $3.67 \mathrm{a}$ & $2.68 \mathrm{a}$ \\
\hline \multicolumn{3}{|l|}{ Split plot (S) } \\
\hline D1L & $3.63 \mathrm{a}$ & $2.78 \mathrm{a}$ \\
\hline D5L & $3.21 \mathrm{a}$ & $2.64 \mathrm{a}$ \\
\hline D1E & $3.36 \mathrm{a}$ & $2.48 \mathrm{a}$ \\
\hline D5E & $3.32 \mathrm{a}$ & $2.73 \mathrm{a}$ \\
\hline PS & $4.96 \mathrm{a}$ & $1.63 \mathrm{a}$ \\
\hline \multicolumn{3}{|l|}{ Split-split plot (SS) } \\
\hline Branches facing North & $4.14 \mathrm{a}$ & $2.24 \mathrm{a}$ \\
\hline Branches Facing South & $3.25 \mathrm{~b}$ & $2.67 \mathrm{a}$ \\
\hline \multicolumn{3}{|l|}{ Variation Coefficient (VC) } \\
\hline $\mathrm{VC}(\%)-\mathrm{P}$ & 37.1 & 139.8 \\
\hline $\mathrm{VC}(\%)-\mathrm{S}$ & 57.5 & 51.2 \\
\hline $\mathrm{VC}(\%)-\mathrm{SS}$ & 37.5 & 47.5 \\
\hline
\end{tabular}

Means followed by the same letter do not differ according to Tukey's test at 5\% significance.

Coffee trees on planting rows of shade trees, distancing one and five meters from the trunk (D1L and D5L), coffee trees on inter-rows of shade trees, parallel to D1L and D5L (D1E and D5E); coffee trees distancing 77 meters from shade tree trunks, in a full-sun field (PS).

Also, between 07.00 and 09.00 , but at LSD, effects of the interactions between shade trees species, spatial distribution and coffee tree solar exposure side were found. Regarding coffee tree solar exposure side, branches facing North had greater $P_{n}$ than ones facing South at PS of $A$. falcata and $P .{ }^{n}$ dubium, D1E and D5E of $C$. grandis (Figure 6). Under $C$. grandis, D1L had greater $P$ than D1E on branches facing South. In branches facing North under $P$. dubium, D1L had lower $P_{n}$ than PS (Figure 6). Coffee trees under P. dubium ${ }^{n}$ had greater $P_{n}$ than those under $C$. grandis at D1E, D5E and PS. Coffee trees at D1L were similar under A. falcata and P. dubium. At D5E and PS of A. falcata, the values of $P_{n}$ were intermediary in relation to the other shade trees (Figure 6).

The values of $P_{n}$ verified at this season were similar to the normal rates reported by DaMatta et al. (2004), between 4 and $12 \mu \mathrm{mol} \mathrm{m}^{-2} \mathrm{~s}^{-1}$. Coffee trees under shade undergo morphological and physiological changes, such as reduction in leaf thickness, number and size of stomata (BALIZA et al., 2012), increase in leaf area (RICCI et al., 2013) and the number of grana per chloroplasts and of thylakoids per granum (DaMATTA, 2004). These adaptations allow a better use of the available light.

Between the time frame from 11.00 to 13.00 , during HSD, coffee trees under A. falcata showed lower $P_{n}$ at PS (Figure 7). Also, coffee trees under C. grandis at D5L and D1E reached superior $P_{n}$ levels than those at PS. There was no difference in $P$ due to spatial distribution of coffee trees under P. dubium (Figure 7).

Other than observed at coffee trees under A. falcata and at D5L of C. grandis (Figure 7), Ferreira (2017) found superior $P_{n}$ at coffee trees inter-rows of shade trees than near the trunk. The same author also reported greater $P_{n}$ in coffee trees under shade than at full sun. 

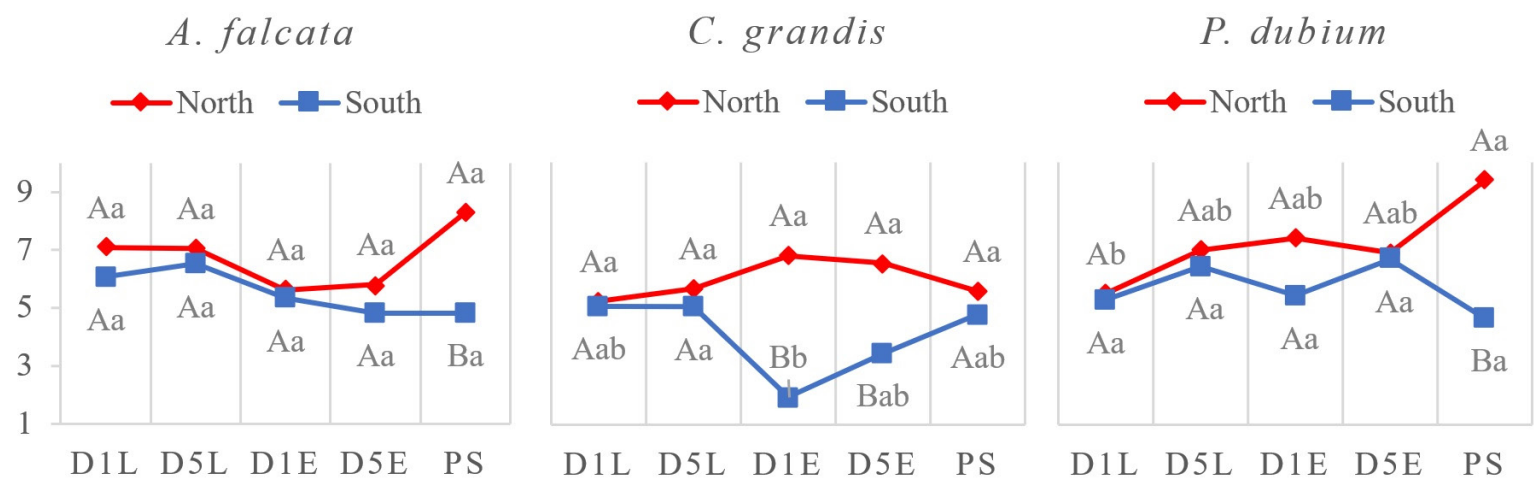

FIGURE 6 - Photosynthetic rate $\left(P_{n}\right)$ of 'IAC Obatã' coffee trees as a function of shade tree species, spatial distribution and coffee tree solar exposure side between 07.00 and 09.00 (solar time), during coffee tree growth season of low sink demand. Santo Antônio do Jardim, SP, 2019.Means followed by the same letters, lower case for spatial distribution and capital for coffee trees solar exposure side, do not differ according to Tukey's test at 5\% significance.Coffee trees on planting rows of shade trees, distancing one and five meters from the trunk (D1L and D5L), coffee trees on inter-rows of shade trees, parallel to D1L and D5L (D1E and D5E); coffee trees distancing 77 meters from shade tree trunks, in a full-sun field (PS).

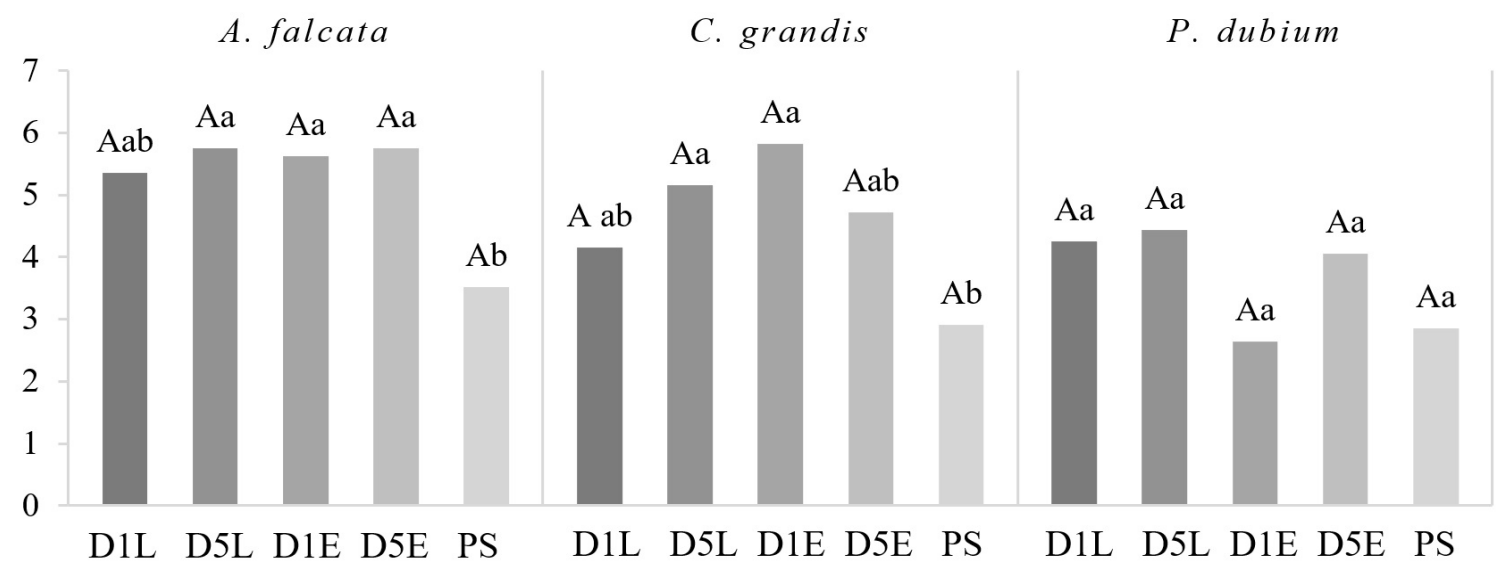

FIGURE 7 - Photosynthetic rate $\left(P_{n}\right)$ of 'IAC Obatã' coffee trees as a function of shade tree species, spatial distribution and coffee tree solar exposure side between 11.00 and 13.00 (solar time), during coffee tree growth season of low sink demand. Santo Antônio do Jardim, SP, 2019.Means followed by the same letters, lower case for spatial distribution and capital for species, do not differ according to Tukey's test at $5 \%$ of significance level. Coffee trees on planting rows of shade trees, distancing one and five meters from the trunk (D1L and D5L), coffee trees on inter-rows of shade trees, parallel to D1L and D5L (D1E and D5E); coffee trees distancing 77 meters from shade tree trunks, in a full-sun field (PS).

\section{CONCLUSIONS}

Canopy density and occupation rate are not homogenous in different seasons and shifts due to shade tree spatial distribution, but do not respond to shade tree species. Low canopy density and high $P A R$ values on the inter-rows of shade trees suggest the need for smaller spacing between trees.

Shade trees decrease $P A R$ to more suitable levels for coffee tree usage, especially at D1L. Planting rows oriented East-West implicates in significant self-shading that increases due to closeness to shading trees trunk. 
During growth season of high sink demand of coffee trees, $P_{n}$ was not decreased by the distance to the shade tree trunk. However, branches facing North showed greater $P_{n}$. During growth season of low sink demand, between 11.00 and 13.00 (solar time), A. falcata allowed superior $P_{n}$ at all location, when compared to PS. However, on coffee trees shaded by $C$. grandis, only the distances of D5L and D1E had greater $P_{n}$ than PS.

\section{ACKNOWLEDGEMENTS}

This study was financed in part by the Coordenação de Aperfeiçoamento de Pessoal de Nível Superior - Brasil (CAPES) - Finance Code 001. The authors would also like to thank Mr. Adorno, owner of Retiro Santo Antônio Farm, his family and staff for the essential support during the execution of this study.

\section{REFERENCES}

ALMEIDA, A. C. S de. Geotecnologias na gestão de propriedades agrícolas cafeeiras. 2016, 45 p. Trabalho de Conclusão de Curso (Bacharel em Agroecologia) Centro de Ciências Agrárias, Universidade Federal de São Carlos, Araras, 2016.

ANDRADE, C. M. S. de, et al. Transmissão de luz em sistemas silvipastoris com eucalipto. Revista Árvore, v. 26, n. 1, pp. 19-23, 2002.

ANDRADE, C. M. S. de; SALMAN, A. K. D.; OLIVEIRA, T. K. de. Guia arbopasto: manual de identificação e seleção de espécies arbóreas para sistemas silvipastoris. Brasília, DF: Embrapa, 345p. 2012.

ARAUJO, W. L. et al. Limitations to photosynthesis in coffee leaves from different canopy positions. Plant Physiology and Biochemistry, v. 46, p. 884-890, 2008.

BALIZA, D. P. et al. Trocas gasosas e características estruturais adaptativas de cafeeiros cultivados em diferentes níveis de radiação. Coffee Science, Lavras, v. 7, n. 3, p. 250-258, set.-dez., 2012.

CAMARGO, M. B. P. de. The impact of climatic variability and climate change on arabic coffee crop in Brazil. Bragantia, v. 69, n.1, pp. 239-247, 2010.

CHARBONNIER, F. et al. Increases light-use efficiency sustains net primary productivity of shaded coffee plants in agroforestry system. Plant, Cell and Environment, v. 40, p. 1592-1608, 2017.
CHARBONNIER, F. et al. Competition for light in heterogeneous canopies: Application of MAESTRA to a coffee (Coffea arabica L.) agroforestry system. Agricultural and Forest Meteorology, v. 181, p. 152169, 2013.

CHAVES, A. R.M. et al. Varying leaf-to-fruit ratios affect branch growth and dieback, with little to no effect on photosynthesis, carbohydrate or mineral pools, in different canopy positions of field-grown coffee trees. Environmental and Experimental Botany, v. 77, p. 207-208, 2012.

COELHO, R. A. et al. Nível de sombreamento, umidade do solo e morfologia do cafeeiro em sistemas agroflorestais. Revista Ceres, Viçosa, v. 57, n.1, p. 095-102, jan.-fev., 2010.

DaMATTA, F. M. Ecophysiological constraints on the production of shaded and unshaded coffee: a review.

Field Crops Research, v. 86, p. 99-114, 2004.

EMPRESA BRASILEIRA DE PESQUISA AGROPECUÁRIA, EMBRAPA. Centro Nacional de Pesquisa de Solo. Sistema brasileiro de classificação de solos. Rio de Janeiro, 2006. 306p.

FERREIRA, R. de P. Ecofisiologia do cafeeiro sombreado com macaúba em sistemas agroflorestais. 2017, 56 f. Dissertação (mestrado) - Universidade Federal de Viçosa, Viçosa, 2017.

FRANCK, N.; VAAST, F. Limmitation of coffee leaf photosynthesis by stomatal conductance and light availability under different shade levels. Trees, v. 23, p. 761-769, 2009.

LEMMON, P. E. A new instrument for measuring forest overstory density. Journal of Forestry, v. 55, n. 9, set., 1957.

LIMA, J. O. S. Aplicação de quatro métodos indiretos na medição de densidade de dossel em fragmentos de mata nativa, recuperada e floresta de Eucalyptus urophylla (S.T. Blake). 2016, 70 p. Dissertação (Mestrado) - Escola Superior de Agricultura "Luiz de Queiroz", Piracicaba, 2016.

LORENZI, H. Árvores brasileiras: manual de identificação e cultivo de plantas arbóreas nativas do Brasil. Nova Odessa, SP: Instituto Plantarum, 2009. 384 p. 
MIAH, M. G. et al. Transformation pf jackfruit (Artocarpus heterophyllus Lam.) orchard into multistory agroforestry incriases system productivity. Agroflorestry Systems, v. 92, n. 6, p. 1687-1697, 2018.

MOREIRA, S. L. S. Produtividade, qualidade do solo e aspectos microclimáticos emsistema agroflorestal de cafeeiro e macaúba. Dissertação mestrado Departamento desolos. Programa de pós-graduação em Agroecologia. Universidade Federal de Viçosa,ViçosaMG, 43,p. 2015.

OLIVEIRA, E. S. de. Arranjos de árvores na decomposição de serapilheira e atributos físicos do solo em cafezal. 2018, 58 f. Dissertação (Mestrado em Agroecologia e Desenvolvimento Rural) - Centro de Ciências Agrárias, Universidade Federal de São Carlos, Araras, 2018.

PADOVAN, M. P. et al. Root distribution and water use in coffee shaded with tabebuia rosea Bertol. and Simarouba glauca DC. compared to full sun coffee in sub-optimal environmental conditions. Agroforest Systems. v. 89, p. 857-868, 2015.

PADOVAN, M. P. et al. Water loss by transpiration and soil evaporation in coffee shaded by Tabebuia rosea bertol. and Simarouba glauca dc. compared to unshaded coffee in sub-optimal environmental conditions. Agricultural and Forest Meteorology, v. 248, pp. 1-14, 2018.
PEZZOPANE, J. R. M. et al. Microclimate in coffee plantation grown under grevillea trees shading. Acta Scientiarum. Agronomy, v. 33, n. 2, pp. 201-206, 2011.

RECOMENDAÇÕES de adubação e calagem para o Estado de São Paulo. 2. ed. Campinas: Instituto Agronômico, 1997. 285 p. (Boletim Técnico ; n. 100).

RICCI, M. dos S. F.; COCHETO JUNIOR, D. G.; ALMEIDA, F. F. D. de. Condições microclimáticas, fenologia e morfologia externa de cafeeiros em sistemas arborizados e a pleno sol. Coffee Science, Lavras, v. 8, n. 3, p. 379-388, jul.-set., 2013.

RONQUIM, J. C. Carbon gain in Coffea arabica during clear and cloudy days in the wet season. Experimental Agriculture, Cambridge-UK, v. 42, p. 147-164, 2006.

SILES, P.; HARMAND, J. M.; VAAST, P. Effects of Inga densiflora on the microclimate of coffee (Coffea arabica L.) and overall biomass under optimal growing conditions in Costa Rica. Agroforestry Systems, v. 78, p. 269-286, 2010.

TAIZ, L. et al. Plant physiology. 6. ed. Massachusetts: Sinauer Associates, 858 p. 2017.

VALENTINI, L. S. de P. et al. Temperatura do ar em sistemas de produção de café arábica em monocultivo e arborizado com seringueira $r$ coqueiro-anão na região de Mococa, SP. Bragantia, Campinas, v. 69, n.4, p. 1005-1010, 2010. 